\title{
A fast and simple method for wild yeast flora detection in winemaking
}

\author{
Francesca Comitini \\ Mariza Stringini \\ Manuela Taccari \\ Maurizio Ciani \\ Dipartimento S.A.I.F.E.T. sez. di \\ Microbiologia Alimentare, Industriale \\ e Ambientale, Università Politecnica \\ delle Marche, Ancona, Italy
}

\begin{abstract}
An easy technique for a fast determination of wild yeast population-colonizing grape must before fermentation is described. The mathematical relationship between viable cell number and oxygen consumption rate was determined using a simple $\mathrm{pO}_{2}$ electrode chamber. This relation was determined in pure cultures belonging to six yeast species related to wine environment and in natural samples of grape must collected at the time of the grape delivery in the wineries. Results indicated a significant relationship between oxygen consumption rate and viable cell count of the wine yeast species tested. The evaluation of natural grape must samples indicated that the presence at pre-fermentative of wide contaminant yeast flora at a level commonly believed responsible for uncontrolled microbiological process in winemaking $\left(>10^{6}\right.$ $\mathrm{CFU} \mathrm{m} \mathrm{m}^{-1}$ ), was easily detected. Since the results are available in a short time, this method could be profitable used to detect the presence of contaminant level of wild yeasts reducing the risk of uncontrolled start fermentation that could compromise the quality of final product.
\end{abstract}

Keywords: wild yeasts contamination, oxygen consumption, $\mathrm{O}_{2}$ probe

\section{Introduction}

Wine quality is influenced by several factors including grapevine variety, yeast strains employed during fermentation processes and winemaking techniques. The role of the yeast population on the fermentation, chemical composition and sensorial properties of wine, has been widely demonstrated. ${ }^{1-3}$ Indeed, microorganisms have a prominent role in determining the chemical composition of wine. They influence the quality of grape prior to harvest and during fermentation metabolizing grape sugars and other components into ethanol, carbon dioxide and hundreds of secondary end-products that, collectively, contribute to the wine character. ${ }^{3}$ Therefore, yeast population and also filamentous fungi and bacteria give a considerable contribution to the chemical composition of wine even if yeasts play the main role during the alcoholic fermentation., ${ }^{2,4}$

Studies on yeast succession during spontaneous fermentations have shown that several non-Saccharomyces yeast species are present at the early stages of the process. ${ }^{5,6}$ These yeast species was progressively replaced by Saccharomyces cerevisiae strains which are more tolerant to alcohol and have better fermentative ability. ${ }^{7-9}$ Several authors noted that yeast diversity during fermentation contributes to the final complexity of wine. ${ }^{10-13}$ However, uncontrolled yeast species presence can produce undesirable compounds. ${ }^{14-16}$ The control of wild microflora could be performed avoiding to collect the damaged grapes, harvesting the grapes at low temperature, reducing the time of grapes transportation between vineyard and cellar, and using antiseptic agents such as $\mathrm{SO}_{2}$.

Sulphur dioxide has a long history of usage as synthetic preservative agent in the manufacture of food, dried fruits and fish, and alcoholic beverages, especially wine where it is used as antioxidant and antiseptic agent. Indeed, in the winemaking industry the inhibition of wild yeasts is obtained by adding this antiseptic agent to musts and inoculating selected strains of $S$. cerevisiae. ${ }^{17-19}$ Since wild yeast flora generally 
shows a lower resistant to sulphite than that exhibited by $S$. cerevisiae strains, selective doses of $\mathrm{SO}_{2}$ are added to grape must. Nowadays, the World Health Organization and the European Economic Community have highlighted the need to reduce the use of this antimicrobial agent in food products because of its toxicity.

In view of $\mathrm{SO}_{2}$ reduction, the quantitative presence of wild microflora on grape berries and in grape must should be monitored to promptly intervene with corrective practices to preserve the quality of final product.

For this reason, it is therefore very important for cellar operators to be able to quickly evaluate the contamination degree of grapes and musts. Traditional procedures, such as standard counting in plate and microscopy observation are the most common methods used to estimate the viable yeast population colonizing grapes and musts at pre-fermentative stages. However, all these practices require specialized equipment, are time-consuming, and deliver results after a long time.

With the present work we propose a new method for a fast detection of viable cell of wild yeast flora present in grape must at the pre-fermentative stages by evaluating the $\mathrm{O}_{2}$ consumption rate of substrate in defined conditions.

\section{Materials and methods}

\section{Microorganisms and media}

Hanseniaspora uvarum DBVPG 3037, Torulaspora delbrueckii DBVPG 6168, Pichia anomala DBVPG 3003, and Candida stellata DBVPG 3827 were from the Industrial Yeast Collection of the University of Perugia (DBVPG), Saccharomyces cerevisiae was a commercial active dry yeast, Fermicru ${ }^{\circledR}$ AR2 strain, and Aureobasidium spp. was isolated from the grape surface during the 2003 vintage. All of these strains were sub-cultured at six-month intervals on YPD agar medium (10 $\mathrm{g} \mathrm{l}^{-1}$ Bacto yeast extract; $20 \mathrm{~g} \mathrm{l}^{-1}$ Bacto peptone; $20 \mathrm{~g} \mathrm{l}^{-1}$ glucose and $18 \mathrm{~g} \mathrm{l}^{-1}$ agar) and maintained at $6{ }^{\circ} \mathrm{C}$.

Pasteurized grape must $\left(90{ }^{\circ} \mathrm{C} \times 20 \mathrm{~min}\right.$.) from Verdicchio cultivar ( $\mathrm{pH} 3.20$; fermentable sugar $22 \% \mathrm{w} / \mathrm{v}$ ), was used as medium for the evaluation of oxygen consumption rate by six yeast species tested.

\section{Experimental conditions}

Before assaying the method directly in natural grape must samples, the $\mathrm{O}_{2}$ consumption rate capability of each yeast species that naturally colonizes the winemaking-related substrates was determined. For each yeast species, the preparation of different suspensions were performed from pre-cultured cells in YPD broth at $25{ }^{\circ} \mathrm{C}$ overnight. Cells were recovered by centrifugation at $4{ }^{\circ} \mathrm{C}(5000 \mathrm{rpm}$ for $10 \mathrm{~min}$ ) and were re-suspended in $\mathrm{H}_{2} \mathrm{O}$. Yeast suspensions with different amounts of viable cells were inoculated into a $0.5-1$ vessel containing $500 \mathrm{ml}$ of grape must with increasing concentrations varying from $10^{6}$ to $10^{8}$ cell $\mathrm{ml}^{-1}$. The vessel content was connected by an Ingold $\mathrm{pO}_{2}$ probe with cathodePt and anode-Ag/AgC, Teflon film, using electron current at $10^{-7}$ Ampers. This probe was associated with a display that showed online values of $\mathrm{O}_{2}$ consumption automatically.

The first step was the oxygen saturation (100\% oxygen dissolved) using a magnetic stirrer to apply a strongly agitation of must for 5 min coupled with an aeration produced by a simple air input system (vvm $\left.0.5 \mathrm{l}^{-1} \mathrm{~min}^{-1}\right)$. After $5 \mathrm{~min}$ the substrate was saturated $\left(100 \% \mathrm{O}_{2}\right.$ dissolved), the agitation and the aeration was stopped, and the measurement of oxygen consumption started. Oxygen consumption was monitored at $25^{\circ} \mathrm{C}$ with intervals of $15 \mathrm{~s}$ for $20 \mathrm{~min}$. Results were subjected to linear regression analysis to calculate the oxygen consumption rate. At the same time, viable cell counts were carried out for each cell concentration and yeast species tested. The viable cell count was evaluated using YPD agar medium to estimate the yeast amount. The relationship between oxygen consumption and cell concentration was determined using Excel 2003 (Microsoft Corp., Redmond, WA, USA). The same modalities of $\mathrm{O}_{2}$ consumption were used for the samples of natural musts collected during the prefermentations stage. The must samples coming from wineries situated in the Marche region of Italy were collected in sterile bottles and transported to the laboratory in cool bags $\left(4{ }^{\circ} \mathrm{C}\right)$ within one hour. At the laboratory the content of each bottle was thermostated at $25^{\circ} \mathrm{C}$ and introduced in the vessel and added of $0.2 \mathrm{ml} \mathrm{l}^{-1}$ of $\mathrm{H}_{2} \mathrm{O}_{2}$ to avoid the possible interaction of the $\mathrm{SO}_{2}$ added in the musts at this stage.

\section{Results and discussion}

One of the main troubles in winemaking is the control of microorganisms that colonize the substrates during the fermentation process and/or develop after the fermentation and cause stack of fermentation or spoiling problems. ${ }^{20,21}$ At the present time, following the market request, the trend in winemaking is the reduction of the use of antiseptic agents such as $\mathrm{SO}_{2}$. In this context, a more strict monitoring of wild microflora at pre-fermentative stages is required to reduce possible deviation of alcoholic fermentation and/or following spoiling activity by wild microflora.

To easily and quickly detect the presence and contamination of wild yeasts in grape must at pre-fermentative stage, $\mathrm{O}_{2}$ 
consumption rate was evaluated using a simple $\mathrm{pO}_{2}$ probe. From this point of view, six yeast species currently found in the grape surfaces and in the must before the start of fermentation were investigated. Preliminarily, the relationship between viable cell counts and $\mathrm{O}_{2}$ consumption was assayed. Very high significant linear regression was found using the yeast concentrations from $10^{6}$ to $10^{8} \mathrm{cell} \mathrm{ml}^{-1}$. A representative result of the linear regressions obtained was reported in Figure 1.

Figure 2 shows the relationship between viable cell count (UFC ml-1) and the rate of oxygen consumption for all six species assayed. Results showed that all yeast species exhibited a significant linear regression between oxygen consumption rate and viable cell count $\left(\mathrm{R}^{2}\right.$ coefficient, $\mathrm{P} \leq 0.01)$. However, the diverse species tested exhibited different rate of $\mathrm{O}_{2}$ consumption in relation to cells concentration showing different coefficient of equation. ${ }^{22}$ In particular, Aurebasidium spp., T. debrueckii, and C. stellata showed a similar equation coefficient between them. Differently, a more vigorous oxygen consumption rate was exhibited by $S$. cerevisiae and $P$. anomala, that showed the same coefficient of equation $(-2 \mathrm{E}-07 \times)$, and H. uvarum (-1E-07×).

To evaluate the possible application of this methodology in a must sample where different species and strains are present, all data were used to define the relationship between oxygen consumption rate and viable cell count. Notwithstanding the differences in oxygen consumption rate in relation to the viable cell count previously found within the different yeast species, the correlation coefficient using all data was statistically significant $\left(\mathrm{P} \leq 0.01 ; \mathrm{R}^{2}=0.4316\right.$, $\mathrm{n}-1=46$ ) (Figure 3).

After these results, the method was used to test several natural grape must samples collected at different prefermentative stages and during two different vintages. Results of all samples tested are summarized in Figure 4a. In this figure, a highly significant correlation between oxygen consumption rate and viable cell concentration was detected (P $\left.<0.01 ; \mathrm{R}^{2}=0.839, \mathrm{n}-1=50\right)$.

However, evaluating separately the consumption rate of the samples determined with a viable cell count $<10^{6}$

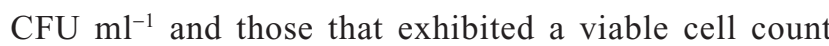
$\geq 10^{6} \mathrm{CFU} \mathrm{ml^{-1 }}$, we obtained different results. Indeed, samples with viable cell count $\geq 10^{6} \mathrm{CFU} \mathrm{ml}^{-1}$ exhibited a significant linear regression $\left(\mathrm{P} \leq 0.01 ; \mathrm{R}^{2}=0.7911\right.$, $\mathrm{n}-1=27$ ) (Figure 4 b) while $\mathrm{O}_{2}$ consumption did not show any correlation in presence of reduced yeast population $\left(<10^{6} \mathrm{CFU} \mathrm{ml}^{-1}\right)$ (Figure $\left.4 \mathrm{c}\right)$. These results indicated that using this method, a good response in terms of linear regression between yeast concentration and $\mathrm{O}_{2}$ consumption could be obtained when the wild yeast contamination level at pre-fermentative stage is closed to the threshold value of $\geq 10^{6} \mathrm{CFU} \mathrm{ml}^{-1}$. Below of this threshold value the method did not able to detect the presence of wild yeast contamination. However, this amount of contamination could be believed a normal level and consequently conform to the winemaking process.

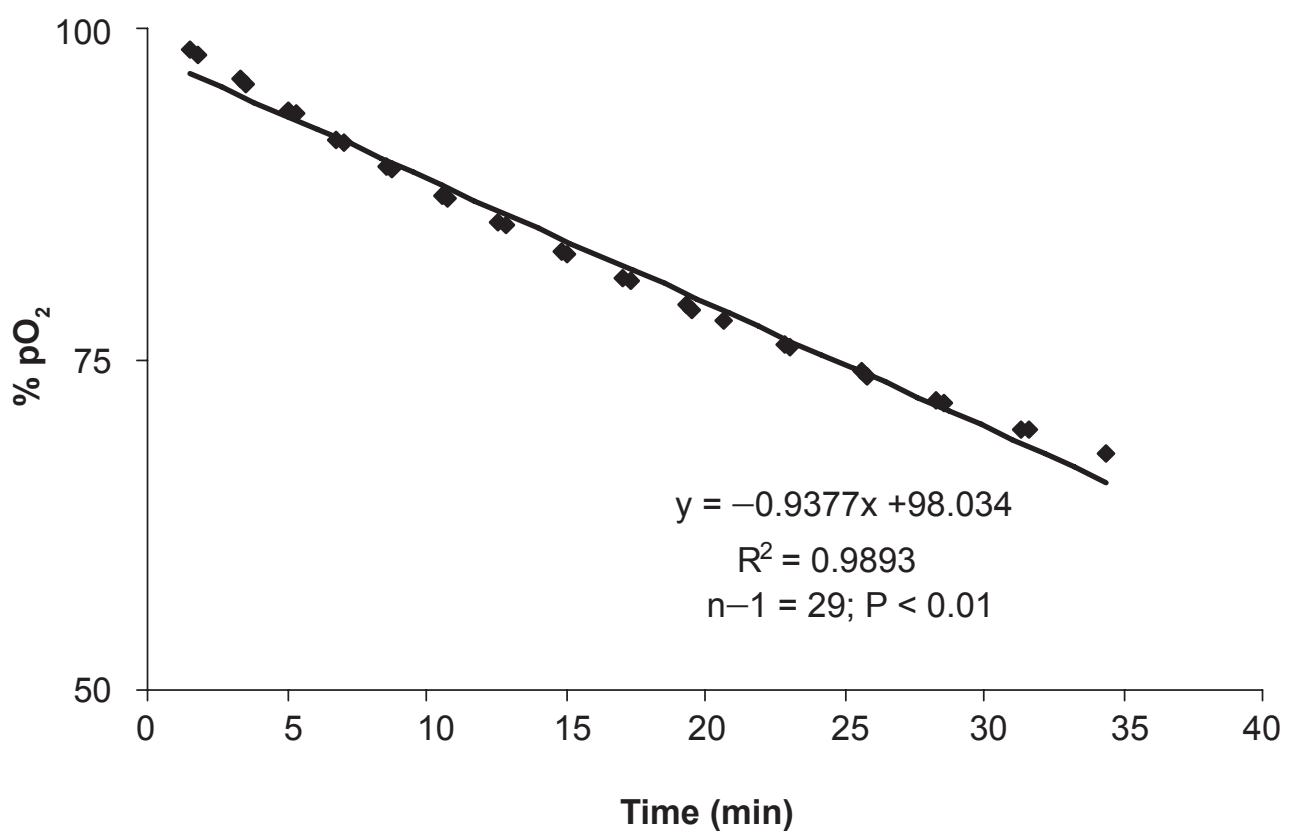

Figure I A representative result of the linear regression $\left(\% \mathrm{pO}_{2}\right.$ dissolved) obtained using Hanseniaspora uvarum at $2 \times 10^{7}$ cell $\mathrm{ml}^{-1}$. 
a)

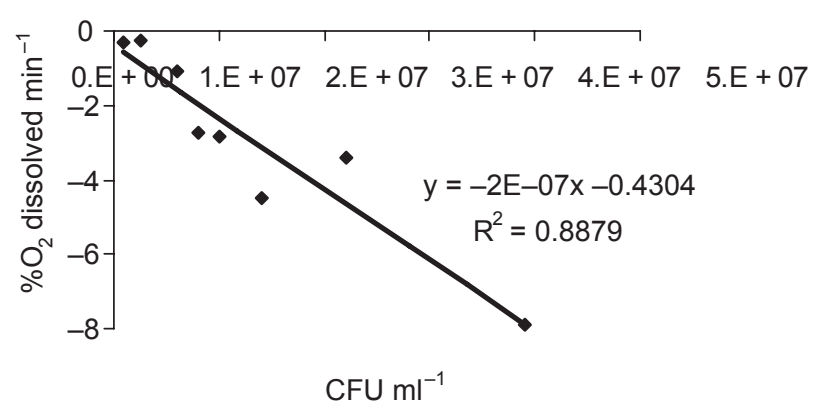

c)

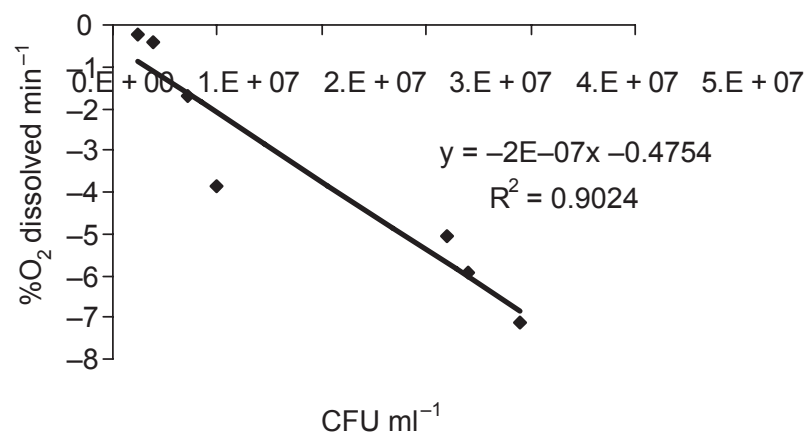

e)

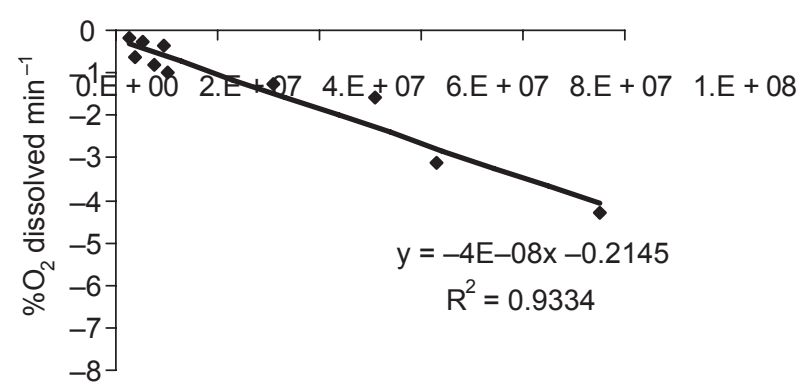

CFU ml ${ }^{-1}$ b)

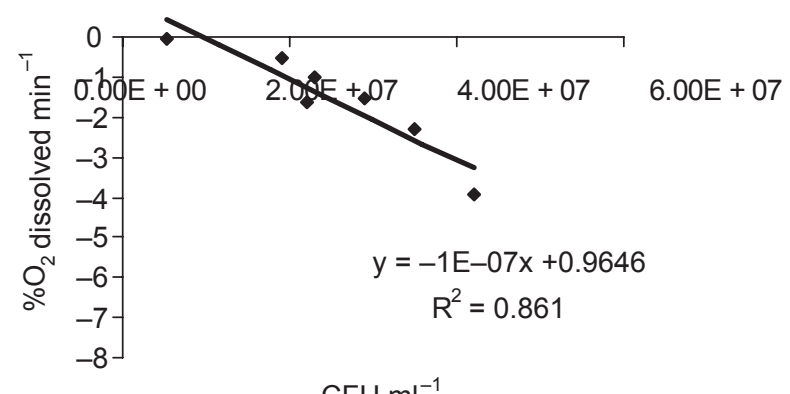

d)

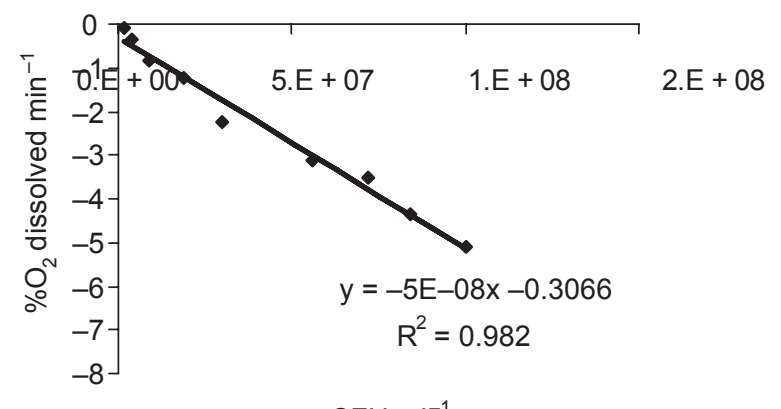

$\mathrm{CFU} \mathrm{ml^{-1 }}$

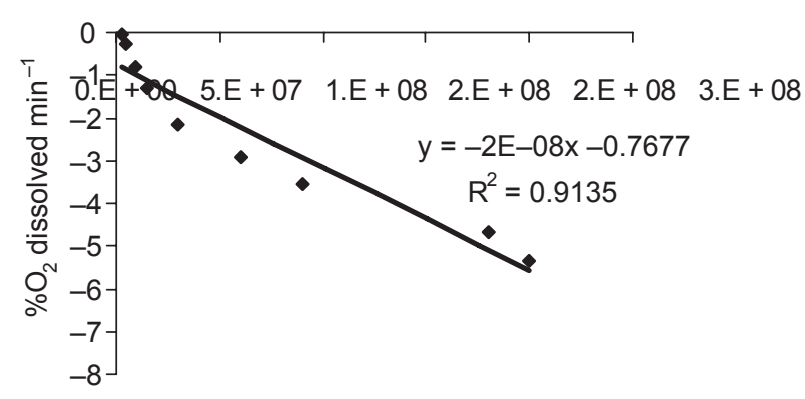

CFU ml $\mathrm{ml}^{-1}$

Figure 2 Relationship between viable cell count and rate of oxygen consumption for: (a) Saccharomyces cerevisiae; (b) Hanseniaspora uvarum; (c) Pichia anomala; (d) Candida stellata; (e) Aureobasidium spp.; and (f) Torulaspora delbrueckii.

In view of a practical application of this method during the pre-fermentative stages, it is possible to individuate the limit value of the rate of oxygen consumption in a must sample. In the condition tested this value should be below the oxygen consumption rate of $-0.5 \% \mathrm{O}_{2}$ dissolved $\mathrm{min}^{-1}$. The presence of vigorous consumption rate is a symptom of an high level of contamination by wild yeast flora and some actions to avoid consequent fermentation problem, should be quickly adopted.
In conclusion, the method proposed is fast, easy, and able to detect the wild yeast contamination level that could cause microbiological problems to the fermentation process in winemaking. In the present work we used a very inexpensive $\mathrm{pO}_{2}$ probe with a limited sensitivity of oxygen-dissolved measurement. However, an increased accuracy could be obtained using a $\mathrm{pO}_{2}$ probe more sensitive to improve the detection limit of contaminating wild yeast flora. 


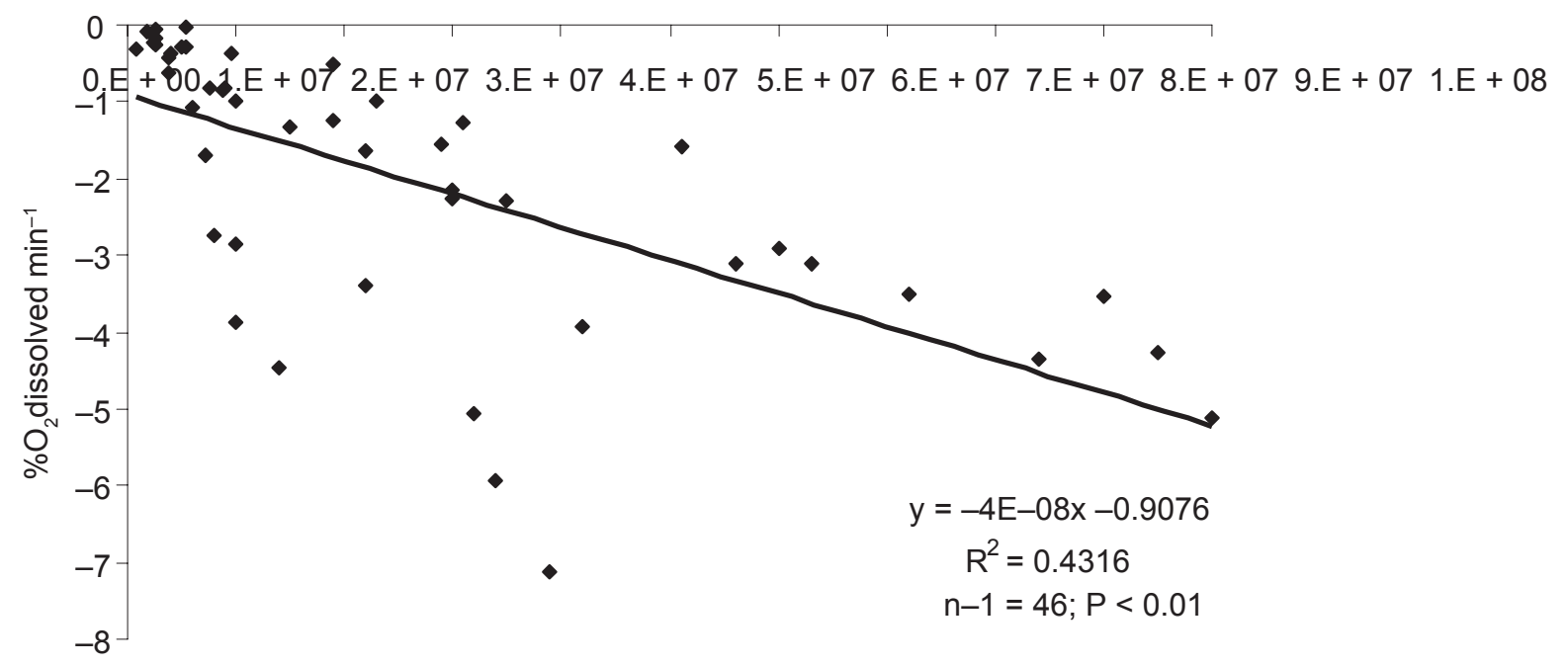

CFU ml-1

Figure 3 Linear regression between oxygen consumption rate and viable cell count for all six species assayed.

(a)

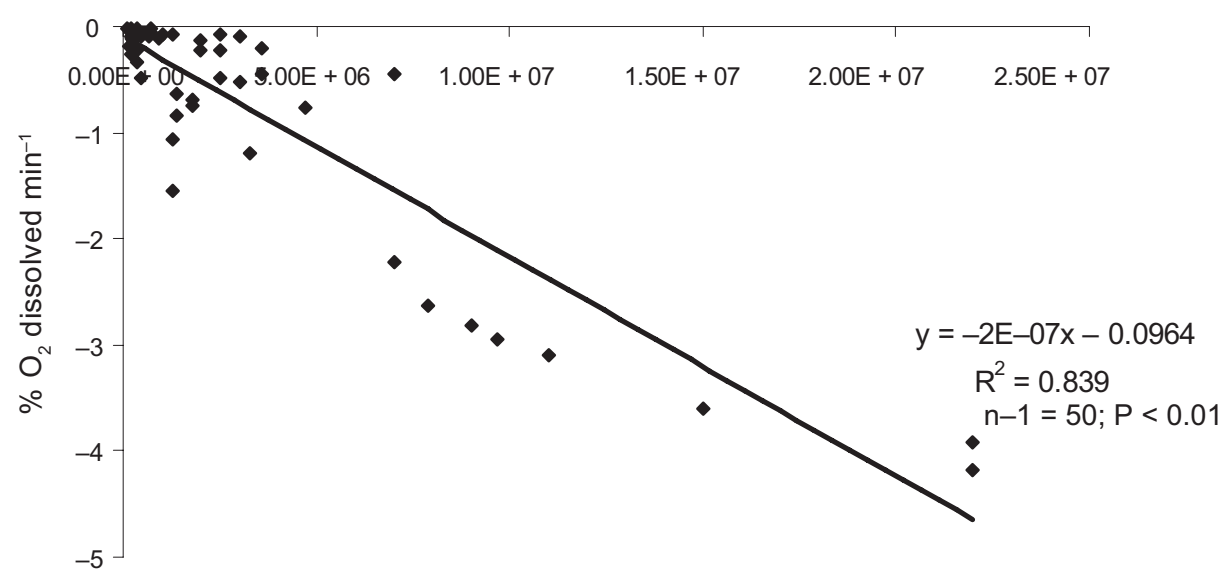

(b)

(c)
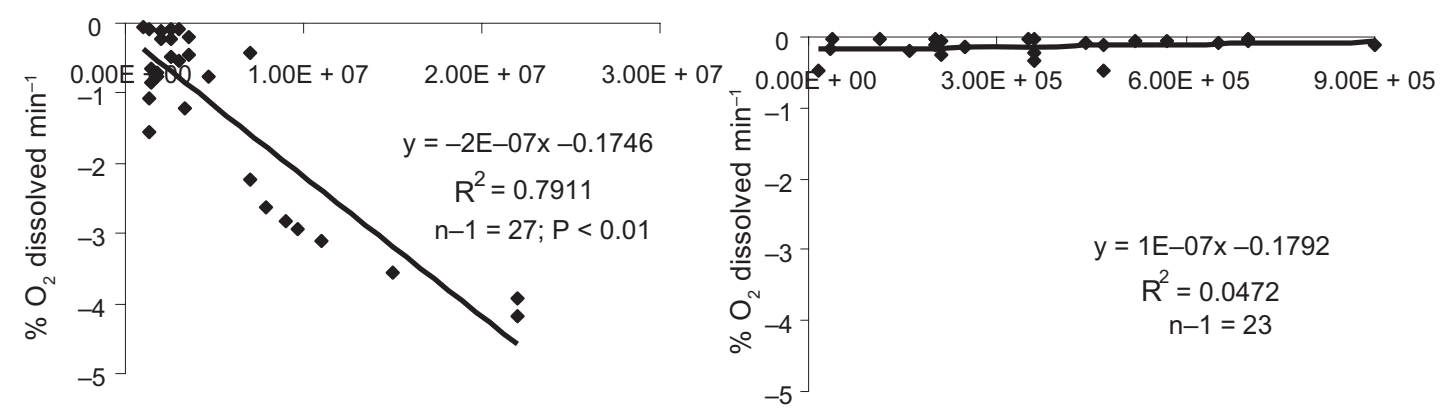

CFU ml-1

CFU $\mathrm{ml}^{-1}$

Figure 4 Monitoring of $\mathrm{O}_{2}$ consumption in natural grape must samples collected at different pre-fermentative stages, during two different vintages: (a) total samples; (b) samples

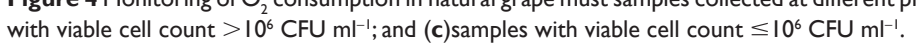




\section{Acknowledgments}

The authors wish to thank the winery Terre Cortesi Moncaro srl for financial support as well as Giuliano D'Ignazi, enologist of the winery, for his kind cooperation. The authors report no conflicts of interest in this work.

\section{References}

1. Fleet GH. Yeast interactions and wine flavour. Int J Food Microbiol. 2003;86:169-180.

2. Fleet GH, Heard GM. Yeasts: Growth during fermentation. In: Fleet GM, editor. Wine Microbiology and Biotechnology. Chur, Switzerland: Harwood Academic Publishers; 1993. p. 27-54.

3. Lambrechts MG, Pretorius IS. Yeast and its importance to wine aroma - a review. S Afr J Enol Vitic. 2000;21:97-129.

4. Muller CJ, Fugelsang KC. Red wine but not white: the importance of fully characterizing wines used in health studies. Am J Clin Nutr. 1997;66:447.

5. Fleet GH, Lafon Lafourcade S, Ribereau-Gayon P. Evolution of yeasts and lactic acid bacteria during fermentation and storage of Bordeaux wines. Appl Envinon Microbiol. 1984;48:1034-1038.

6. Pardo I, García MJ, Zúñiga M, Uruburu F. Dynamics of microbial populations during fermentation of wines from the Utiel-Requena region of Spain. Appl Environ Microbiol. 1989;55:539-541.

7. Constantí M, Poblet M, Arola L, Mas A, Guillamón JM. Analysis of yeast populations during alcoholic fermentation in a newly established winery. Am J Enol Vitic. 1997;48:339-344.

8. Egli CM, Edinger WD, Mitrakul CM, Henick-Kling T. Dynamics of indigenous and inoculated yeast populations and their effects on the sensory character of Riesling and Chardonnay wines. J Appl Microbiol. 1998;85:779-789.

9. Beltran G, Torija MJ, Novo M, et al. Analysis of yeast populations during alcoholic fermentation: a six year follow-up study. Syst Appl Microbiol. 2002;25:287-293.
10. Mateo JJ, Jimenez M, Huerta T, Pastor A. Contribution of different yeasts isolated from musts of Monastrell grapes to the aroma of wine. Int J Food Microbiol. 1991;14:153-160.

11. Gil JV, Mateo JJ, Jimenez M, Pastor A, Huerta T. Aroma compounds in wine as influenced by apiculate yeasts. J Food Sci. 1996;61:1247-1249.

12. Lema C, García-Jares C, Orriols I, Angulo L. Contribution of Saccharomyces and non-Saccharomyces populations to the production of some components of Albariño wine aroma. Am J Enol Vitic. 1996;47:206-216.

13. Ciani M, Beco L Comitini F. Fermentation behaviour and metabolic interactions of multistarter wine yeast fermentations. Int J Food Microbiol. 2006;108:239-245.

14. Esteve-Zarzoso B, Manzanares P, Ramón D, Querol A. The role of non-Saccharomyces yeasts in industrial winemaking. Int Microbiol. 1998;1:143-148.

15. van Keulen H, Lindmark DG, Zeman EK, Gerlosky W. Yeasts present during spontaneous fermentation of Lake Erie Chardonnay, Pinot Gris and Riesling. Antonie van Leeuwenhoek. 2003;83:149-154.

16. Blanco P, Vázquez-Alén M, Losada A. Influence of yeast population on characteristics of the wine obtained in spontaneous and inoculated fermentations of must from Vitis vinifera Lado. J Ind Microbiol Biotechnol. 2008;35:183-188.

17. Henick-Kling T, Edinger W, Daniel P, Monk P. Selective effects of sulfur dioxide and yeast starter culture addition on indigenous yeast populations and sensory characteristics of wine. J Appl Microbiol. 1998;84:865-876.

18. Pretorius IS. Tailoring wine yeasts for the new millennium: novel approaches to the ancient art of winemaking. Yeasts. 2000;16:675-729.

19. Mendoza M, Manca de Nadra MC, Bru E, Farı' as ME. Influence of wine-related physicochemical factors on the growth and metabolism of non-Saccharomyces and Saccharomyces yeasts in mixed culture. $J$ Ind Microbiol Biotechnol. 2008;PMID: 18953586 [Epub ahead of print].

20. Renouf V, Claisse O, and Lonvaud-Founel A. Inventorying and monitoring of wine microbial consortia. Appl Microbiol Biotechnol. 2007;75:149-164.

21. Fleet GH. Wine yeasts for the future. FEMS Yeast Res. 2008;8:979-995.

22. Rosini G. Corradini P. Uso di una sonda per il rilievo dell' $\mathrm{O}_{2}$ nella valutazione della vitalità di starters per vinificazione. Ann Microbiol. 1987;37:217-223. 